\title{
Incidental Extrapulmonary Findings in Low-Dose CT of the Thorax
}

\author{
Zeynep Nilüfer Tekin ${ }^{1}$ iD , Ali Türk² (iD , Süha Alzafer ${ }^{3}$ iD , Zeynep Bilgi ${ }^{4}$ (iD \\ Tuna Demirbaş $^{5}$ (D) , Özlem Barutçu ${ }^{6}$ (iD
}

Department of Radiology, Medeniyet University Göztepe Training and Research Hospital, Istanbul, Turkey

${ }^{2}$ Department of Radiology, Acıbadem Bakırköy Hospital, Istanbul, Turkey

${ }^{3}$ Department of Pulmonary Medicine, Acıbadem University, Istanbul, Turkey

${ }^{4}$ Department of Thoracic Surgery, Medeniyet University Göztepe Training and Research Hospital, Istanbul, Turkey

${ }^{5}$ Department of Radiology, University of Health Sciences Bagcilar Training and Research Hospital, Istanbul, Turkey

${ }^{6}$ Department of Radiology, Acıbadem University, Istanbul, Turkey

Zeynep Nilüfer TEKIN

Ali TÜRK

Süha ALZAFER

Zeynep BiLGi

Tuna DEMIRBAŞ

Özlem BARUTÇU

Correspondence: Zeynep Nilüfer Tekin Department of Radiology, Medeniyet University Göztepe Training and Research Hospital, Istanbul, Turkey

Phone: +905059231853

E-mail: drnilufer@gmail.com

\begin{abstract}
Purpose: The aim of the study is to evaluate the prevalence of extrapulmonary findings in low-dose computed tomography (LDCT) of the thorax.

Methods: Patients who were referred to the radiology department by the department of pulmonary medicine between June 2016 and January 2018 for LDCT examination to assess either a certain or a potential pulmonary disease were identified. Images were retrospectively re-evaluated and findings were categorized according to organ system (Total of 8 groups including cardiac, vascular, mediastinal, abdominal, skeletal, thyroidal, breast and muscular-soft tissue). The LDCT was performed by using a 64-detector CT scanner with scanning parameters standardized as $120 \mathrm{kVp}$ and $20 \mathrm{mAs}$ with 3 mm slice thickness.
\end{abstract}

Results: 102 patients (41 female, 61 male) aged between 25 and 90 years (mean age: $54.5 \pm 14.3$ years) were included in the final assessment. 87 (85.3\%) out of 102 patients had total 245 incidental extrapulmonary findings. Abdominal pathologies were the most common findings (62 patients $(60.8 \%))$. Overall, 26 extrapulmonary findings led to further work-up or consultation.

Conclusion: Incidental extrapulmonary findings can be detected commonly in LDCT of the thorax. Radiologists should be aware of evaluating all the structures in the scanning area by following a systematic approach in the reading of such studies in order to identify possible pathologies and guide the clinician for the accurate management of patients.

Keywords: Low dose computed tomography, thorax, extrapulmonary findings, incidental.

\section{Düşük Doz Toraks BT'de İnsidental Ekstrapulmoner Bulgular}

ÖZET

Amaç : Çalışmanın amacı toraksın düşük doz bilgisayarlı tomografisinde (DDBT) ekstrapulmoner bulguların prevalansını değerlendirmektir.

Yöntemler: Haziran 2016 - Ocak 2018 tarihleri arasında göğüs hastalıkları anabilim dalı tarafından belirli veya olası bir akciğer hastalı̆ı̆ını değerlendirmek amacıyla radyoloji bölümüne DDBT incelemesi için yönlendirilen hastalar belirlendi. Görüntüler retrospektif olarak yeniden değerlendirildi ve bulgular organ sistemine göre sınıflandırıldı (Kardiyak, vasküler, mediastinal, abdominal, iskelet, tiroid, meme ve kas-yumuşak doku olmak üzere toplam 8 grup). DDBT, $120 \mathrm{kVp}$ ve $3 \mathrm{~mm}$ kesit kalınlığında 20 mA olarak standartlaştıııımış tarama parametrelerine sahip 64 dedektörlü bir BT tarayıı kullanılarak gerçekleştirildi.

Bulgular : Değerlendirmeye 25-90 yaşları arasında (ortalama yaş: $54,5 \pm 14,3$ yıl) 102 hasta (41 kadın, 61 erkek) dahil edildi. 102 hastanın 87'sinde $(\% 85,3)$ toplam 245 insidental ekstrapulmoner bulgu vardı. Abdominal patolojiler en sık görülen bulgulardı (62 hasta $(\% 60,8))$. Toplamda, 26 ekstrapulmoner bulgu için ileri tetkik veya konsültasyon istendi.

Sonuç: İnsidental ekstrapulmoner bulgular, toraksın DDBT'sinde yaygın olarak izlenebilmektedir. Radyologlar, olası patolojileri belirlemek ve doğru hasta yönetimi için klinisyene rehberlik etmek amacı ile bu tür incelemelerin okunmasında sistematik bir yaklaşım izlemeli ve tarama alanındaki tüm yapıları değerlendirmelidir.

Anahtar kelimeler: Düşük doz bilgisayarlı tomografi, toraks, ekstrapulmoner bulgular, insidental.

$\begin{array}{ll}\text { Received } & : 2 \text { July } 2021 \\ \text { Accepted } & : 140 \text { ctober } 2021\end{array}$


W ith the advance of imaging technology, the introduction of multidetector $\mathrm{CT}$ has revolutionized the diagnostic process. However radiation dose especially for follow-up examinations still remains as an issue. Incorporating the LDCT based on reduced radiation dose via reducing the tube current principle into the diagnostic algorithm without compromising image quality of lung, have reduced the unwanted effects of radiation (1).

LDCT is commonly used in long term follow-up of pulmonary parenchymal nodules especially in young patients $(2,3)$. A randomized multicenter controlled trial showed that imaging with LDCT reduces lung cancer and all-cause mortality by $20 \%$ and $6.7 \%$, respectively(4).

Presence of different structures other than lungs in the thoracic imaging with LDCT which has reduced image quality than diagnostic $\mathrm{CT}$ raises the question of how frequently incidental findings might be seen in other extraparanchymal tissues and organs in the scanning area. Thus, patients may require further imaging, follow-up, or biopsy to characterize these unexpected findings, or additional treatments may be added to clinical management. There are also opposing views in the literature about the necessity of systematically searching incidental extrapulmonary findings $(5,6)$.

The aim of this study is to analyze the prevalence and distribution of extrapulmonary findings in LDCT with the purpose of contribution to the literature.

\section{MATERIAL AND METHODS}

\section{Study Design and Patient Selection}

The local institutional review board approved this retrospective study. The study population was consisted of 102 consecutive patients ( 41 female, 61 male) aged between 25 and 90 years (mean age: $54.5 \pm 14.3$ years) who were referred to the radiology department by the department of pulmonary medicine between June 2016 and January 2018 for LDCT of the thorax to evaluate either a certain or a potential pulmonary disease.

\section{Low-dose-CT Imaging}

LDCT examinations of thorax were performed using a 64-detector CT scanner (Definition, Siemens, Forcheim, Germany) with following imaging parameters without IV or oral contrast material: acquisition $24 \times 1.2 \mathrm{~mm}$, slice collimation $1.2 \mathrm{~mm}$, slice width $3 \mathrm{~mm}$, pitch 1.2, tube current $20 \mathrm{~mA}$; voltage $120 \mathrm{kVp}$. Scanning was performed in supine position and images were obtained from the lower neck to the upper abdomen in a single breath hold. Axial imaging data were postprocessed (Leonardo workstation, Siemens Medical Solutions) and coronal reconstructions were performed.

\section{Image Analysis}

LDCT images of chest were retrospectively reevaluated for extrapulmonary findings by a 10-year experienced thoracic radiologist. In our study, extrapulmonary findings were defined as pathologies to be seen outside the lung parenchyma. Extrapulmonary findings were categorized in 8 groups as follows: cardiac, vascular, mediastinal, abdominal, skeletal, thyroidal, breast and muscular-soft tissue. In each group detected pathologies were recorded and subgrouped accordingly.

Further assessment options were provided for follow-up modalities or repeated imaging intervals by the radiologist (eg: progression of lung nodule, PET follow-up may be considered, semi-solid renal mass, ultrasound follow-up is recommended).

\section{Statistical Analysis}

Data were expressed as frequencies for categorical variables. Categorical variables were compared via Chi-square test in SPSS software (version 16.0; SPSS; Chicago, Illinois, USA). Statistical significance was interpreted when $p$ values were below 0.05 .

\section{RESULTS}

$85.3 \%$ of the study population $(n=87)$ had at least one incidental extrapulmonary finding. 245 incidental extrapulmonary findings were observed in all patients. Involvement of more than one organ system was noted in $72.5 \%(n=74)$ of the patients.

Abdominal pathologies were the most common extraparenchymal findings found in $60.8 \%$ of the patients ( $\mathrm{n}$ : 62). Hepatosteatosis and sliding hiatal hernia were seen in $37.3 \%$ (n: 38 ) and $11.8 \%$ of all patients with extrapulmonary findings ( $n: 12$ ) respectively (Table 1 ). The breakdown of cumulative extrapulmonary findings are provided in Table 1. 
Table 1: Distribution of incidental extrapulmonary findings in LDCT of chest in 102 patients. Finding were aligned according to descending frequency in each category

\begin{tabular}{|c|c|c|}
\hline Category & Incidental extrapulmonary findings in LDCT of chest & Number of patients ( $n$ ) \\
\hline \multirow{18}{*}{ ABDOMINAL } & Hepatosteatosis & 38 \\
\hline & Sliding hernia & 12 \\
\hline & Renal cysts & 10 \\
\hline & Cystic hepatic lesions & 6 \\
\hline & Hepatic parenchymal calcifications & 5 \\
\hline & Splenic calcifications & 4 \\
\hline & Adrenal hyperplasia & 3 \\
\hline & Adrenal adenoma & 2 \\
\hline & Liver masses & 2 \\
\hline & Bochdalek hernia & 2 \\
\hline & Cholelithiasis & 1 \\
\hline & Gastric diverticulum & 1 \\
\hline & Misty mesentery with mesenteric lymph nodes & 1 \\
\hline & Abdominal aortic aneursym & 1 \\
\hline & Splenic artery aneurysm & 1 \\
\hline & Renal angiomyolipoma & 1 \\
\hline & Renal stone & 1 \\
\hline & Renal parenchymal thinning & 1 \\
\hline \multirow{9}{*}{ SKELETAL } & Degeneration & 59 \\
\hline & Scoliosis & 6 \\
\hline & Hemangioma & 3 \\
\hline & Diffuse idiopathic skeletal hyperosteosis (DISH) & 3 \\
\hline & Sclerotic lesions & 2 \\
\hline & Lytic lesions & 2 \\
\hline & Simple bone cysst & 2 \\
\hline & Old healed fractures & 2 \\
\hline & Compression fracture & 1 \\
\hline \multirow{7}{*}{ CARDIAC } & Coronary artery calcifications & 34 \\
\hline & Valvular calcifications & 9 \\
\hline & Increased cardiothoracic ratio & 7 \\
\hline & Pericardial effusion & 6 \\
\hline & Pericardial cyst & 2 \\
\hline & Pericardial thickening & 2 \\
\hline & Increased pericardial fat tissue thickness & 1 \\
\hline \multirow{3}{*}{ VASCULAR } & Thoracic aortic atherosclerosis & 40 \\
\hline & Ascending aortic dilatation & 8 \\
\hline & Dilatation of pulmonary artery & 2 \\
\hline \multirow{2}{*}{ THYROIDAL } & Thyroid nodule & 7 \\
\hline & Thyroid gland hyperplasia & 4 \\
\hline \multirow{5}{*}{ BREAST } & Tumoral masses & 4 \\
\hline & Breast calcifications & 3 \\
\hline & Gynecomastia & 3 \\
\hline & Postoperative change & 2 \\
\hline & Asymmetry in breast tissue & 1 \\
\hline
\end{tabular}


Table 1: Distribution of incidental extrapulmonary findings in LDCT of chest in 102 patients. Finding were aligned according to descending frequency in each category (continuation of Table 1)

\begin{tabular}{|c|l|c|}
\hline Category & \multicolumn{1}{|c|}{ Incidental extrapulmonary findings in LDCT of chest } & Number of patients (n) \\
\hline MEDIASTINAL & Mediastinal lymphadenopathy & 8 \\
\hline \multirow{3}{*}{ MUSCULAR -SOFT TISSUE } & Tumoral mass & 2 \\
\cline { 2 - 4 } & Skin thickening & 1 \\
\cline { 2 - 3 } & Subcutenous edema & 1 \\
\cline { 2 - 4 } & Axillary lymphadenopathy & 1 \\
\hline
\end{tabular}

In the female population ( $\mathrm{n}: 41,40.2 \%$ ) the most common extraparenchymal findings were skeletal $(65.9 \%)$ and abdominal (51.2\%) pathologies. The categoric distribution of other extrapulmonary findings in females were $58.5 \%$ cardiac, $48.8 \%$ vascular, $17.1 \%$ breast, $14.6 \%$ thyroidal, 9.8\% mediastinal and $7.3 \%$ muscular-soft tissue.

For the male population ( $n: 61,59.8 \%$ ) the most common extraparenchymal findings were abdominal pathologies (67.2\%) followed by bone pathologies (55.7\%). The other extrapulmonary findings in males in descending order were in vascular $(36.1 \%)$, cardiac $(34.4 \%)$, mediastinal (11.5\%), thyroidal (6.6\%), breast (4.9\%) and muscular-soft tissue $(1.6 \%)$ categories.

While most of those incidental findings were age related/ degenerative changes, in 24 patients, extrapulmonary findings were deemed significant enough to warrant additional consultations/imaging studies. 4 patients with breast findings (tumoral masses) (Figure 1), 9 cardiovascular findings (ascending aorta dilatation, pericardial masses etc.), 3 patients with renal masses (apart from simple cysts), 2 patients with surrenal nodules were among those patients. 14 patients had progression of known lung nodule. Mean age for patients with clinically significant findings was $57 \pm 14.9$ vs $52.3 \pm 13.5$ without $(p=0.051) .4$ patients had both progression of known nodule and clinical significant extrapulmonary finding.

\section{DISCUSSION}

Globally increasing rates of pulmonary diseases including lung cancer necessitated new advances in the radiological assessment of the patients who were referred to radiology clinics for CT scan. LDCT is also being used as a lung cancer screening tool for a certain subset of patients, improving the prognosis greatly (4). All those practices increase the prevalence of the LDCT together with the diagnoses of "incidentalomas".

Incidental findings have been classified according to clinical significance by many authors (5-8) but "potentially significant" and "insignificant" terms are open to interpretation and differs among investigators. In this study, we not only included reported incidental findings, the LDCT images were also reevaluated for incidental extrapulmonary findings regardless of reports by a radiologist specialized in thoracic imaging. Thus, some low-risk extrapulmonary findings were not recorded by different radiologists and the possible differences between the reports or uncorrect interpretations were tried to be minimized by this standardization as analysis of incidental findings was the primary aim of this retrospective study.
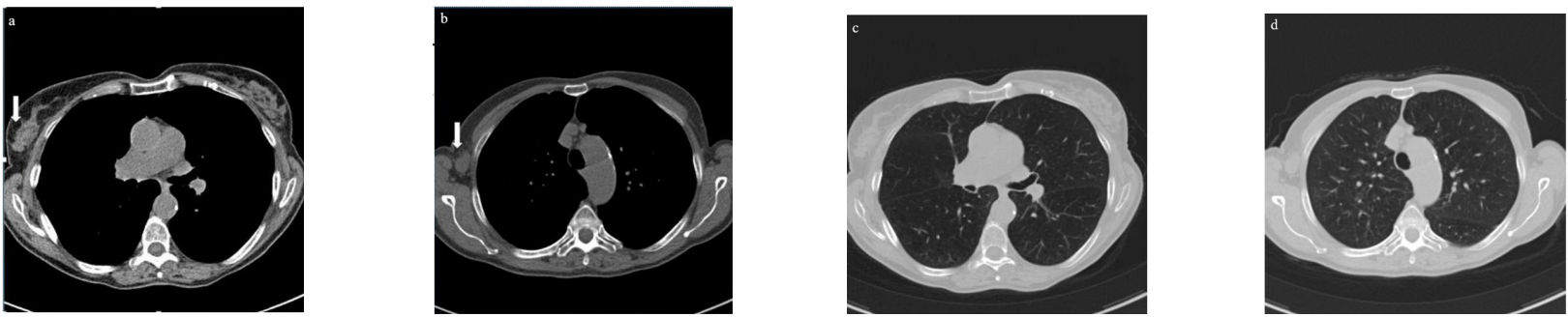

Figure 1a-d: Axial LDCT image in mediastinal window setting showing a lobulated tumoral mass in right breast (a) accompanied by right axillary LAP (b) of a 43 years old female. In the lung window setting of same image the lesion in right breast (c) and right axillary LAP (d) were not so distinguishable. Later the lesion was confirmed as invasive ductal carcinoma histopathologically. 
Weng et al reported that the performance of LDCT was comparable to standard-dose CT and LDCT was superior to digital radiography for detection of pulmonary nodule, mediastinal lymphadenopathy ( $>10 \mathrm{~mm}$ in the short axis) and pleural effusion (9). Naidich et al, in their preliminary observations, showed that at all levels of the thorax, visualization of parenchymal structures was not affected by decreasing the milliamperage in LDCT protocol especially in the pediatric population, as well as for screening patients at high risk for developing lung cancer $(3,10)$. In another study thoracic non-osseous lesions were detected in cancer patients in LDCT images acquired as a part of skeletal SPECT/CT examinations (11). In the literature, it also stated that the image quality of LDCT was satisfactory for both mediastinal and lung windows in the followup of lung cancer (12).

Dinkel et al reported that, during follow-up of patients with malignant lymphoma and extrapulmonary primary tumors, the impact of the thorax LDCT on image quality and lesion conspicuity was as high as standard-dose CT (13). In our study only baseline LDCT imaging were performed without additional postprocessing which improves image quality of LDCT.

Since the field of view in CT exams includes several additional organ systems, it is important to evaluate all of those structures for potential abnormalities. In our study abdominal pathologies were by far most common incidental finding seen in $60,8 \%$ ( $n: 62$ ) of patients and among those hepatosteatosis was the most common extraparenchymal finding. While our study did not reveal a definite case of an incidental cancer, Pinsky et al reported 104 cases of renal carcinoma in a cohort of more than 26000 patients who received LDCT for National Lung Screening Trial (enrollment from 2002-2004)(14). They also concluded that incidental abnormal abdominal findings were common (39.1\%) in screens with renal cancer versus $4.1 \%$ in screens without.

Incidental thyroid carcinoma was also found to be a notso-rare entity in a different secondary analysis study done on the National Lung Screening Trial (enrollment from 2002-2004), 35 thyroid cancers were found with a 7, 8 fold increased risk in patients with any above-diaphragm abnormality (15).

Thoracic radiology experience in interpretation of LDCT is an important factor affecting diagnostic assessment. In our study, a 10-year experienced radiologist specialized in thoracic imaging retrospectively re-evaluated the images of LDCT rather than a general radiologist as commonly seen in the literature (8).

In the study of Nguyen et al extrapulmonary findings were assigned to five organ systems (cardiovascular, thyroid adrenal, renal, and hepatobiliary) among prospectively acquired data on 17,309 participants who underwent chest LDCT. In their study, extrapulmonary findings were noted in $58.7 \%$ of the study group (16). In our study, among the 102 patients who underwent LDCT incidental extrapulmonary findings were observed in $85,3 \%$ of the patients which was a relatively high rate as additional categories were added (skeletal, breast and muscular-soft tissue).

The category "S" in Lung-RADS reporting system defines other findings than those pertaining to lung cancer and can be scored between $0-4$. In a retrospective investigation that involved 581 patients who received baseline LDCT for lung cancer screening, 141 incidentalomas were described in reports but were not labelled with the $S$ modifier. Since incidental findings were commonly identified on chest $\mathrm{CT}$ for lung cancer screening, the authors concluded that usage of the $S$ modifier within Lung-RADS is inconsistent (17).

Relatively small sample size and retrospective design are the main limitations of this study. In a prospective study with larger study population diversity of encountered extrapulmonary findings would be much higher.

\section{CONCLUSION}

Our study highlighted that with LDCT of the thorax incidental extrapulmonary findings could be frequently detected. Radiologists reading LDCT of the thorax should be aware of possible incidental findings that occur outside the lung parenchyma and, therefore, should systematically evaluate all the structures in the scanning area, not only with the lung window settings but also with mediastinal and bone window settings. It is critical that radiologists should provide clear and appropriate recommendations to clinicians on how to manage incidental findings. Thus, this will prevent under-diagnosis, necessary clinical management is provided and unnecessary follow-up and possible medicolegal issues are avoided. 


\section{References}

1. Kim Y, Kim YK, Lee BE, et al. Ultra-low-dose $C T$ of the thorax using iterative reconstruction: evaluation of image quality and radiation dose reduction. AJR Am J Roentgenol.2015;204:1197-202. DOI: 10.2214/AJR.14.13629

2. Rampinelli C, Origgi D and Bellomi M. Low-dose CT: technique, reading methods and image interpretation. Cancer imaging. 2012;12:548. DOI: 10.1102/1470-7330.2012.0049

3. Naidich DP, Bankier AA, Macmahon $\mathrm{H}$, et al. Recommendations for the management of subsolid pulmonary nodules detected at CT: a statement from the Fleischner Society. Radiology. 2013;266:30417. DOI:10.1148/radiol.12120628

4. Aberle DR, Adams AM, Berg CD, et al. Reduced lung-cancer mortality with low-dose computed tomographic screening. N Engl J Med. 2011;365:395-409. DOI:10.1056/NEJMoa1102873

5. Rampinelli C, Preda L, Maniglio M, et al. Extrapulmonary malignancies detected at lung cancer screening. Radiology. 2011;261:293-9. DOI:10.1148/radiol.11102231

6. Van De Wiel JC, Wang Y, Xu DM, et al. Neglectable benefit of searching for incidental findings in the Dutch-Belgian lung cancer screening trial (NELSON) using low-dose multidetector CT. Eur Radiol. 2007;17:1474-82. DOI:10.1007/s00330-006-0532-7

7. Kucharczyk MJ, Menezes RJ, Mcgregor A, et al. Assessing the impact of incidental findings in a lung cancer screening study by using lowdose computed tomography. . Can Assoc Radiol J. 2011;62:141-5. DOI:10.1016/j.carj.2010.02.008

8. Swensen SJ, Jett JR, Sloan JA, et al. Screening for lung cancer with low-dose spiral computed tomography. Am J Respir Crit Care Med. 2002;165:508-13. DOI:10.1164/ajrccm.165.4.2107006

9. Weng MJ, Wu MT, Pan HB, et al. The feasibility of low-dose CT for pulmonary metastasis in patients with primary gynecologic malignancy. Clin Imaging. 2004;28:408-14. DOI:10.1016/ s0899-7071(03)00246-8

10. Naidich DP, Marshall CH, Gribbin C, et al. Low-dose CT of the lungs: preliminary observations. Radiology. 1990;175:729-31. DOI:10.1148/radiology.175.3.2343122

11. Wuest W, Lell M, May MS, et al. Thoracic non-osseous lesions in cancer patients detected in low-dose CT images acquired as part of skeletal SPECT/CT examinations. Nuklearmedizin. 2015;54:1737. DOI:10.3413/Nukmed-0721-15-02

12. Yamada $\mathrm{T}$, Ono $\mathrm{S}$, Tsuboi $\mathrm{M}$, et al. Low-dose $\mathrm{CT}$ of the thorax in cancer follow-up. . Eur J Radiol. 2004;51:169-74. DOI:10.1016/j. ejrad.2003.09.017

13. Dinkel HP, Sonnenschein M, Hoppe $H$, et al. Low-dose multislice CT of the thorax in follow-up of malignant lymphoma and extrapulmonary primary tumors. Eur Radiol. 2003;13:1241-9. DOI:10.1007/s00330-002-1647-0

14. Pinsky PF, Dunn B, Gierada D, et al. Incidental renal tumours on low-dose CT lung cancer screening exams. J Med Screen. 2017;24(2):104-109. DOI:10.1177/0969141316657115

15. Loomans-Kropp HA, Dunn BK, Kramer BS, et al. Thyroid Incidentalomas in Association With Low-Dose Computed Tomography in the National Lung Screening Trial. Am J Epidemiol. 2020;189(1):27-33. DOI:10.1093/aje/kwz219

16. Nguyen XV, Davies L, Eastwood JD, et al. Extrapulmonary Findings and Malignancies in Participants Screened With Chest CT in the National Lung Screening Trial. J Am Coll Radiol. 2017;14:324-30. DOI:10.1016/j.jacr.2016.09.044

17. Reiter MJ, Nemesure A, Madu E, et al. Frequency and distribution of incidental findings deemed appropriate for $\mathrm{S}$ modifier designation on low-dose $\mathrm{CT}$ in a lung cancer screening program. Lung Cancer. 2018;120:1-6. DOI:10.1016/j.lungcan.2018.03.017 